\title{
How Electoral Systems Can Influence Policy Innovation
}

\author{
Salomon Orellana
}

This paper argues that in certain areas of policy, electoral systems can influence policy innovation (how early countries will adopt certain policies). Electoral systems influence the number of parties that win representation and thereby influence the diversity of perspectives included in the policymaking process. It is argued here that this diversity facilitates elite and public consideration of new issues and ideas, and consequently, it leads to earlier debate and action on these issues and ideas. This dynamic is particularly relevant to controversial issues and ideas that major parties may be hesitant to address and that minor parties may be more incentivized to promote. In this paper, two issues/ideas are considered: extending rights to same-sex couples and making material sacrifices to protect the environment. I show that countries with more proportional electoral systems tend to act earlier to protect the environment and that they tend to be early adopters of civil union legislation. These results are also supported by World Values Survey data showing public preference patterns that support these policy outcomes.

KEY WORDS: electoral systems, parties, information diversity, policy innovation, public preferences

\section{Introduction}

This paper argues that a particular feature of political information environments-the diversity of perspectives magnified by the electoral system-influences policy innovation or how quickly countries will adopt certain policies. The argument hinges on the assumption that diversity is a form of openness and, as such, that it affects a society's flow of information. The flow of information will be greater in societies with institutions that facilitate the expression of a more diverse range of perspectives, and especially of dissenting perspectives. This variation in information should be of great consequence to a wide range of political outcomes, but especially to policy innovation and concomitant changes in public preferences.

The diversity framework is particularly relevant to research on the political consequences of electoral institutions; indeed, few settings are as suitable to the study of the effects of information diversity. By influencing the number of parties that win representation, electoral institutions profoundly influence the breadth and diversity of political discourse. They particularly influence whether minor parties and their often marginalized concerns and ideas will be heard. This dynamic affects how quickly countries will debate particular issues and ideas (especially issues that can be considered sensitive or controversial at a particular point in time), and 
consequently how quickly countries will adopt certain legislation on those issues and ideas.

This paper focuses on two issues that have in the last few decades become salient across wealthier societies: the extension of rights to same-sex couples and making material sacrifices to protect the environment. I argue that these issues are likely to receive more attention in countries with institutions that facilitate the expression of diverse perspectives (particularly, proportional representation [PR]). Consequently, I show that this dynamic helps explain (i) why citizens in countries with more proportional electoral systems tend to show more tolerance for homosexuality and more support for protecting the environment and (ii) why these countries also tend to have higher levels of policy innovation on these issues.

\section{Electoral Institutions and the Information Environment}

Decades of research shows that electoral institutions influence many areas of politics. The core of this research establishes that electoral institutions influence the character and nature of party systems (Duverger, 1954; Lijphart, 1994; Rae, 1971). But they are also credited with influencing virtually every other important characteristic of a democracy, including minority representation (Bowler, Donovan, \& Brockington, 2003), the success of interest groups and social movements (Heidenheimer, 1973; Kitschelt, 1986), responsiveness to public opinion (Powell, 2000), legitimacy (Banducci, Donovan, \& Karp, 1999; Banducci \& Karp, 1999), conflict mitigation (Lijphart, 1969), and corruption (Chang \& Golden, 2006). We are also learning that electoral institutions influence a broad array of policy outcomes, including wealth redistribution (Alesina \& Glaeser, 2004) and several other elements of economic policy (Persson \& Tabellini, 2003).

This study focuses on how electoral institutions, by influencing the diversity of perspectives given voice in the political system, affect policy innovation (or how quickly countries adopt certain policies). To begin with, much research shows that electoral institutions influence the diversity of perspectives included at various stages of the representation process. In comparison with majoritarian systems (i.e., single-member-district systems), countries with institutions such as PR will have more parties contesting elections (Katz, 1997) and more parties winning seats in the legislature (Lijphart, 1999). Proportional systems also favor the inclusion of a greater number of parties in the executive (Blais \& Carty, 1987) and tend to grant the opposition more influence in the legislature (Powell, 2000).

These dynamics are of consequence to the information environment because the number of parties in a system affects the number of issue areas considered by the political system (Lijphart, 1999, pp. 78-89). Moreover, because PR is associated with more parties that are small, extreme, and ideological, it is also associated with competition over a broader political spectrum. As demonstrated by Katz (1997, pp. 150-60), the party systems in PR systems represent a wider range of positions on a left-right scale than do the party systems in countries with majoritarian systems. They also represent a wider range of positions in most other policy areas, such as taxation and environmental policy. We should expect, then, that more issue areas will 
tend to receive attention under multiparty proportional systems than under fewerparty majoritarian systems. Under the proportional systems, we should also expect to see a more diverse range of positions/ideas taken on any given issue.

Orellana (2009) shows that these dynamics are reflected in elite discourse and media coverage. Most important for the purposes of this study, an increase in the number of parties that win seats in a legislature was found to be associated with an increase in the diversity of issues and ideas debated in the legislature and that receive attention from the media. By winning even a few seats, minor parties gained entry into elite debate and dramatically increased their share of media attention. They also brought much greater attention to "new" issues and ideas.

Thus, past research strongly suggests that electoral systems affect the diversity of perspectives magnified by the political system and that thereby they affect how quickly certain issues will be debated and addressed. In particular, more proportional electoral systems give minor parties greater opportunity to introduce many issues/ideas that at a given point in time can be considered sensitive or controversial. Many of these sensitive ideas will be neglected by the major parties either because these parties find those ideas objectionable or because they find them too risky to address even if they agree with them. The next section demonstrates that these dynamics help explain patterns in another area critical to policy innovation: public preferences.

\section{Electoral Institutions and Changes in Public Preferences}

The importance of the information dynamics, discussed above, for policy innovation is underscored by research showing that electoral systems can influence public opinion, a factor known to affect policymaking. ${ }^{1}$ Several studies have shown, for example, that electoral systems influence various elements of public opinion and behavior, including participation in elections, satisfaction with political institutions, the tendency to cast tactical votes, attachments to parties (Karp, Vowles, Banducci, \& Donovan, 2002; Niemi, Whitten, \& Franklin, 1992; Norris, 2004), and political sophistication (Gordon \& Segura, 1997). Here, it is argued that the information mechanisms described in the previous section influence public attitudes in rather fine ways; they can actually help explain why some societies come to hold certain preferences earlier than others.

If electoral systems affect the diversity of party systems, and consequently, the degree to which marginal ideas will be disseminated in a political system, then we can expect that electoral systems will affect how soon and how frequently the public will be exposed to certain messages. Namely, electoral systems should be expected to affect access to information on what I refer to here as "sensitive" issues and "sensitive" policy positions. My conceptualization of sensitivity involves two concerns. First, sensitive issues and sensitive policy positions are those that more centrist politicians and parties will find difficult to discuss. Consequently, many of these kinds of issues and positions are more likely to be introduced by minor parties, which tend to have more space to dissent. Second, sensitivity is a time-dependent concept. An issue that is sensitive at a particular point in time is one that could be 
ordinary in another. For example, an issue like racial equality was once a sensitive issue in most countries, and today it is largely taken for granted that discrimination based on race should be illegal.

To identify more current examples of sensitive issues, we can turn to recent literature on modernization and the rise of "postmaterialistic" preferences. Modernization theorists have argued that socioeconomic development is associated with technological innovations, increases in labor productivity, occupational specialization, rising levels of education, rising levels of income, and the diversification of human interactions, and that these factors in turn produce coherent changes in culture and politics. ${ }^{2}$ In general, these forces encourage the development of more "cosmopolitan," "secular," "tolerant," and "self-expressive" social attitudes. With respect to particular attitudes and behaviors, Inglehart and Welzel (2005) note that in recent decades, wealthy societies have experienced cultural changes that include the supplanting of institutionalized religion with individualized spiritual concerns, greater support for protecting the environment, and greater tolerance toward issues such as homosexuality, gender equality, and divorce.

Thus, the postmaterialism literature points to several issues that are currently transitioning from controversial to ordinary, particularly across wealthier countries. This paper concentrates on two of these issues: the rights of same-sex couples and protection of the environment. ${ }^{3}$ These two issues are relatively difficult for centrist policymakers in two-party systems to address because they are imbued with controversy and political costs, especially when they are first introduced. An issue such as extending rights to same-sex couples involves advancing the interests of a historically unpopular minority group, while protecting the environment requires asking the public to make material sacrifices.

To some extent, protecting the environment is not a conventional sensitive issue; it is in some ways a valence issue, meaning that it is an issue that few people disagree with. Even so, levels of commitment do tend to decline as people begin to realize that there are costs involved (Inglehart, 1995). A case in point is the issue of gasoline taxes in the United States. While a strong majority of Americans support protecting the environment, it is unimaginable that a presidential candidate in the United States would ever run on the position that taxes on gasoline should be higher-even though Americans pay lower taxes on gasoline than the citizens of most other countries. Indeed, both parties tend to attack each other when gasoline prices rise. Without a minor party to promote a dissenting position, the elite consensus reinforces the position that gasoline taxes should be low, and consequently, we should expect the American public to more readily oppose increases in gasoline taxes.

Evidence from New Zealand, which shifted from a majoritarian to a proportional electoral system, confirms that these "postmaterialistic" issues are more likely to receive attention under proportional systems. Orellana (2009) and Hayward and Rudd (2000) found that once the New Zealand Green Party was able to win seats under the PR system, it successfully brought attention to the issues it promoted. News coverage of the environment dramatically increased, as did coverage of changing sexual norms. More importantly, the adoption of PR brought greater attention to several specific proposals on the environment that can be considered politically 
risky, including proposals on eco-taxes and the use of industrial hemp. A similar dynamic emerged for the issue area of sexual norms. In 1999, thanks in large part to the minor parties, there was for the first time coverage of positions supporting the rights of gay/lesbian/transgender individuals.

It should be emphasized at this point that this evolution of preferences is not precluded by majoritarian systems. All democratic systems permit the flow of significant amounts of information, and we should therefore observe this evolution of preferences in all advanced democracies-and indeed, Inglehart's work suggests that this is happening. The key point is that the evolution is more rapid under electoral institutions that facilitate the expression of diverse ideological perspectives. Institutions such as PR should facilitate the discussion of sensitive issues and sensitive policy positions enough to affect public consideration of such issues and positions, and enough that electoral institutions can help explain the variation in attitudes toward sensitive issues that exists across democratic countries.

\section{Measurement}

To explore empirically how electoral systems affect public preferences on the environment and homosexuality, data from the 1999 World Values Survey were used (European Values Study Group and World Values Survey Association, 2004). The questions used were the following:

Please tell me for each of the following statements whether you think it can always be justified, never be justified, or something in between: Homosexuality. 1 Never justifiable-10 Always justifiable.

Can you tell me whether you agree strongly, agree, disagree or strongly disagree? The Government should reduce environmental pollution, but it should not cost me any money.

The question on homosexuality is relatively straightforward and directly tracks tolerance of homosexuality. The question on the environment is a little more subtle. As discussed by Inglehart (1995), direct questions on the environment tend to capture the valence nature (the popularity) of protecting the environment. In most developed countries, direct questions on environmental protection reveal strong majorities in favor of protecting the environment. However, this result changes when respondents are asked the question presented above, which uses wording that makes it easier for respondents to say no to making sacrifices to protect the environment. Inglehart thus found that this wording captures more of the hidden unwillingness to make sacrifices.

The proportion of respondents showing support in each country for each question $^{4}$ was regressed on the key independent variable for this analysis: the effective threshold. Unlike categorical measures that distinguish between majoritarian, mixedmember, and proportional systems, Lijphart's (1994) effective threshold measure provides a continuous measure of the type of electoral system employed by a country. ${ }^{5}$ The effective threshold is a more refined indicator of the barriers parties 
must overcome to win seats, taking into account the average district magnitude ${ }^{6}$ (the number of seats up for grabs in a district) and any national legal threshold present in a country. As such, it is also a good indicator of the obstacles parties face in winning legislative seats and the incentives parties will face when they compete for support, capturing the degree to which parties may need to moderate their policy agendas and messages in order to receive enough votes to win legislative seats.

Fewer parties will be able to win seats, and more message moderation will be required in more majoritarian systems (such as in the United States), which are coded as requiring 37.5 percent of the vote in order for a party to win a seat in a single-member district. More parties will be able to win seats in systems such as the Netherlands, where the effective threshold is 1 percent, and especially small parties will be rather free to explore a wider range of policy issues and positions. Data from the World Bank Database of Political Institutions (Beck, Clarke, Groff, Keefer, \& Walsh, 2001) and Inter-Parliamentary Union are used to calculate the average effective threshold for the lower chamber in each country over 10 years, from 1988 to 1997. Taking the average over the last 10 years should capture the effects of any relevant reforms undertaken by countries. To reflect the expectation that there is likely a "diminishing rate of return" from moving from a pure proportional system to a more and more majoritarian system, this variable was logged.

A second key variable is demographic heterogeneity. This variable can be considered another source of information diversity, but its expected effects are unclear. Ethnic diversity can conceivably increase the diversity of political discourse, but it can also introduce tensions that may negatively affect the flow of information. To capture the effect of this factor, data are taken from Yeoh Kok Kheng's (2001) measure of ethnic fractionalization, which accounts for religious, racial, and linguistic cleavages.

Controls are also introduced for the number of years a country is considered democratic, the level of economic development, and predominant religious affiliations. The information effects of electoral institutions should be rather minimal and even nonexistent in countries that are nondemocratic and particularly in systems that limit free speech and the media. For this reason, the number of years that a country is regarded as free (by Freedom House) is controlled for (years free). This variable was also used to select the countries included in the sample. Only countries that were free for 10 years or more, through 1999, are included in the analysis. For most models, the values are taken for the period from 1972 to 1999; for the civil union legislation model (analyzed in the next section), the values are taken for the period from 1972 to the year when the country adopted the civil union legislation.

Economic development is controlled for because modernization studies suggest that citizens with greater material wealth begin thinking less about "lower-order" issues such as economic security and more about "higher-order" issues such as quality of life and concern for the environment (Inglehart \& Welzel, 2005). Moreover, controlling for economic development should also help control for the effects of various information technologies that become more prevalent as a country becomes wealthier. Here, economic development is measured with data from the Penn World Tables and the CIA World Factbook on GDP per capita. ${ }^{8}$ With respect to religious 
affiliation, Roman Catholic societies have historically tended to resist secularization even in the face of communist rule and socioeconomic development (Inglehart \& Welzel, 2005, p. 75). This should produce direct consequences for issues such as homosexuality. The proportion of Protestants was also controlled for, while all other religious groups were excluded because they appear in negligible numbers in the countries examined.

\section{Results}

Table 1 displays the regression results for public preferences. We can see, first, that the effective threshold significantly predicts attitudes toward both the environment and homosexuality. As the effective threshold increases, as we move toward majoritarianism, we find less support for each of these issues. Substantively, a change in the effective threshold from its lowest value to its highest value (which is equivalent to switching from a nearly pure proportional system like the Netherlands' to a majoritarian system like the United States') is associated with a nearly 9 percent drop in support for protecting the environment and an 8 percent drop in support for homosexuality.

These results provide strong evidence that electoral systems can influence how quickly public preferences change on certain sensitive issues. We know from Inglehart and from regular polling data that tolerance of homosexuality and support for the environment are on the rise in all the countries analyzed here. But the fact that proportional systems are in the lead on these changes confirms that information-particularly, an elite discourse that is ideologically diverse-plays a critical role.

With respect to the other explanatory variables, it is interesting to note that ethnic fractionalization predicts positive support for homosexuality (although only at the 0.1 level) but has no statistically significant influence on support for environmental protection. This finding suggests that ethnic fractionalization does help introduce the

Table 1. Electoral Systems and Public Preferences

\begin{tabular}{lcc}
\hline & Environment & Homosexuality \\
\hline Effective threshold (logged) & $-0.087^{* *}(0.033)$ & $-0.080^{* * *}(0.023)$ \\
Ethnic fractionalization & $0.077(0.128)$ & $0.173^{*}(0.089)$ \\
Years free (through 1999) & $0.001(0.007)$ & $0.005(0.005)$ \\
GDP per capita (in 1999) & $0.002(0.006)$ & $0.010^{* *}(0.004)$ \\
Catholic & $-0.226(0.097)$ & $-0.092(0.067)$ \\
Protestant & $0.098(0.117)$ & $0.125(0.080)$ \\
Constant & $0.556^{* * *}(0.161)$ & $0.245^{* *}(0.116)$ \\
$R^{2}$ & 0.579 & 0.723 \\
$N$ (countries) & 26 & 35 \\
* $^{2} \leq 0.1{ }^{* *} p \leq 0.05,{ }^{* * *} p \leq 0.01$ (2-sided). & \\
Standard errors in parentheses. & \\
Source of survey data: World Values Survey (1999). \\
Sources of effective threshold data: World Bank and Inter- \\
Parliamentary Union.
\end{tabular}


public to new social issues such as the concerns of same-sex couples; however, it does not encourage debate on new nonsocial issues such as the environment.

As for the control variables, most of them produced no significant effects. The only significant effect came from economic development on support for homosexuality. This result is consonant with Inglehart's thesis that economic development is linked with increases in postmaterialism. It should be noted that the results for the democracy and economic development variables should be interpreted with caution, mainly because countries were in part selected on these variables. Most countries in the sample were relatively wealthy and democratic, and consequently, their effects in this analysis are likely understated.

\section{Electoral Institutions and Policy Innovation}

The theoretical discussion and the results of the previous section suggest that there are policy areas in which countries with more proportional electoral systems are likely to innovate. That is, there are policies that countries with PR are more likely to adopt first and that other countries will eventually adopt. In this section, attention is given to policy innovation on the rights to same-sex couples and protection of the environment. Other "postmaterialistic" issues were considered-including euthanasia, embryonic cell research, and decriminalization of prostitution-but unfortunately, there is not yet enough variation across a sufficiently large sample of countries on these issues. At the time of this writing, too few countries have adopted relevant legislation on these issues, although it should be noted that the only two countries to formally legalize euthanasia (the Netherlands and Belgium) are countries with PR. For issues such as abortion and divorce, data from earlier time periods are required, and this is particularly problematic for data on public preferences and electoral systems.

\section{Measurement}

Policy innovation on same-sex issues is operationalized as the amount of time it takes a country to adopt civil union legislation. In recent decades, countries have begun to extend rights to same-sex couples mainly by passing civil union legislation and in some cases by legalizing same-sex marriage. The period under consideration begins in 1988 (the year before Denmark became the first country to adopt civil union legislation) and ends in 2006. For this analysis, each country was given a score based on the number of years it took to adopt the legislation.

An event history model is used to analyze the adoption of civil union legislation because the sample of countries can be considered censored. Through 2006, only 21 countries had adopted civil union legislation, and this figure is likely to rise with the passage of time. Event history models permit the modeling of the probability that an event will happen, given that, through the period observed, the event has not happened (Box-Steffensmeier \& Jones, 2004). A Weibull hazard model is used to analyze a total of 57 countries (that were democratic for at least 10 years through 2004) because it is capable of handling the expectation that the hazard rate changes 
as time passes. In this case, it is expected that once the first nations have adopted civil union legislation, it should become easier for other nations to do so.

Policy innovation on environmental protection is measured here in three ways. Since the 1992 Rio Earth Summit and the 1997 Kyoto Protocol, many countries have sought to reduce greenhouse gas emissions. Particularly since the Kyoto Protocol, many countries have sought to reduce their $\mathrm{CO}_{2}$ emissions to below their levels in 1990. If it is easier for countries with more proportional electoral systems to enact measures that protect the environment but at the same impose material costs, then we might expect to see that electoral systems affect the progress countries have made on reducing $\mathrm{CO}_{2}$ emissions. To explore this possibility, data on $\mathrm{CO}_{2}$ emissions per capita were collected from the International Energy Agency (2009). The dependent variable in this case is the percentage change in $\mathrm{CO}_{2}$ emissions per capita in OECD countries from 1990 to 2007.

For a more nuanced look at the relationship between electoral systems and environmental action, we can also explore the relationship between electoral systems and the price of gasoline. It should be more difficult for majoritarian governments to discuss increasing taxes on gasoline, and this should decrease public support for this action. Proportional systems should permit minor parties to offer dissenting positions that might argue for increases in "eco-taxes." These dynamics should affect the rate of taxation on gasoline and should ultimately affect gas prices. Data on gasoline prices were collected from the Deutsche Gesellschaft für Technische Zusammenarbeit (Ebert, Metschies, Schmid, \& Wagner, 2009). The dependent variable in this case is then the retail price of gasoline in OECD countries as of November 2008 (in U.S. cents/liter).

Finally, a more general measure of environmental performance was analyzed: the Pilot Environmental Performance Index (EPI). This index was developed by the Global Leaders of Tomorrow World Economic Forum in collaboration with the Yale Center for Environmental Law and Policy and the Center for International Earth Science Information Network of Columbia University. ${ }^{9}$ It was designed to measure environmental results at a national level by gauging performance on and rates of change in air quality, water quality, greenhouse gas emissions, and land protection. The index was collected in 2002 and is available for 21 democratic countries.

Ordinary least squares was used to analyze all three continuous dependent indicators of environmental policy innovation. The independent variables in this section are the same as those used in the previous section, including the effective threshold (averaged through 2004), ethnic fractionalization, the number of years a country was considered democratic, GDP per capita (for 2004), and the proportion of citizens who are Catholic or Protestant. The one difference is that the model for $\mathrm{CO}_{2}$ emissions controls for the starting level of $\mathrm{CO}_{2}$ in 1990 instead of GDP per capita. The starting level of $\mathrm{CO}_{2}$ should still control for the level of economic development, but more importantly, it should control for the effects of starting at different levels of $\mathrm{CO}_{2}$ emissions. If there is a diminishing rate of returns, then countries starting at higher levels of emissions should have an advantage. On the other hand, some of the countries starting at lower levels of emissions were at lower levels of development 
and thus increased their emissions as they caught up to the levels of development of the other OECD countries. Thus, because of rapid development, Spain increased its emissions considerably over the period analyzed, while Britain considerably decreased its emissions, even though Spain ultimately finished 2007 with lower emissions per capita than Britain.

\section{Results}

The results of the regressions are reported in Table 2. We are first able to observe that the effective threshold has a negative and significant effect (at the 0.01 level) on the adoption of civil union legislation. The more majoritarian a country, the less likely it is to adopt this kind of legislation. In particular, a change from a pure proportional system to a pure majoritarian system is associated with a 65 percent decrease in the "hazard" or "risk" that a nation will adopt civil union legislation. ${ }^{10}$

No other explanatory variable significantly predicts the adoption of civil union legislation, including the level of economic wealth, even though this model does include more developing countries. A final point about this model is that the duration parameter $(p)$ for this model is significantly above 1.0 , at 2.8 , indicating that the "risk" that a nation will adopt civil union legislation does indeed increase with time. Once the first country adopts civil union legislation, it becomes easier for other countries to do so.

In the case of environmental performance, the results suggest that the effective threshold has a significant effect (at the 0.05 level) on all three indicators in the expected direction. Substantively, a move from a system of pure PR to a pure majoritarian system (equivalent to moving from the Netherlands to the United States) shifts the percentage change in $\mathrm{CO}_{2}$ emissions by 11 percent in the positive direction, toward increasing emissions. The same move also decreases gas prices by 13 percent, which means gas taxes tend to be lower in majoritarian countries, and it decreases the score on the environmental performance index by approximately 4.5 percent.

Taken together, these results suggest not just that electoral systems affect environmental performance, but that they do so in particular ways. By allowing dissenters to discuss costs, more proportional systems are able to impose those costs largely with the acceptance of the public. This dynamic is particularly reflected in the prices for gasoline. But the innovative nature of the policy outcomes is also reflected in the ability of proportional countries to respond earlier to dilemmas-such as global warming and environmental degradation-which all countries are seeking to address.

No other variables significantly affected all three environmental performance indicators. In fact, the only other significant effects observed were the positive effects of Catholic (0.1 level) and Protestant (0.01 level) background on the EPI. Again, however, the effects of variables such as economic development and democratic freedom are likely reduced by the use of samples that overrepresent wealthy, democratic countries. 


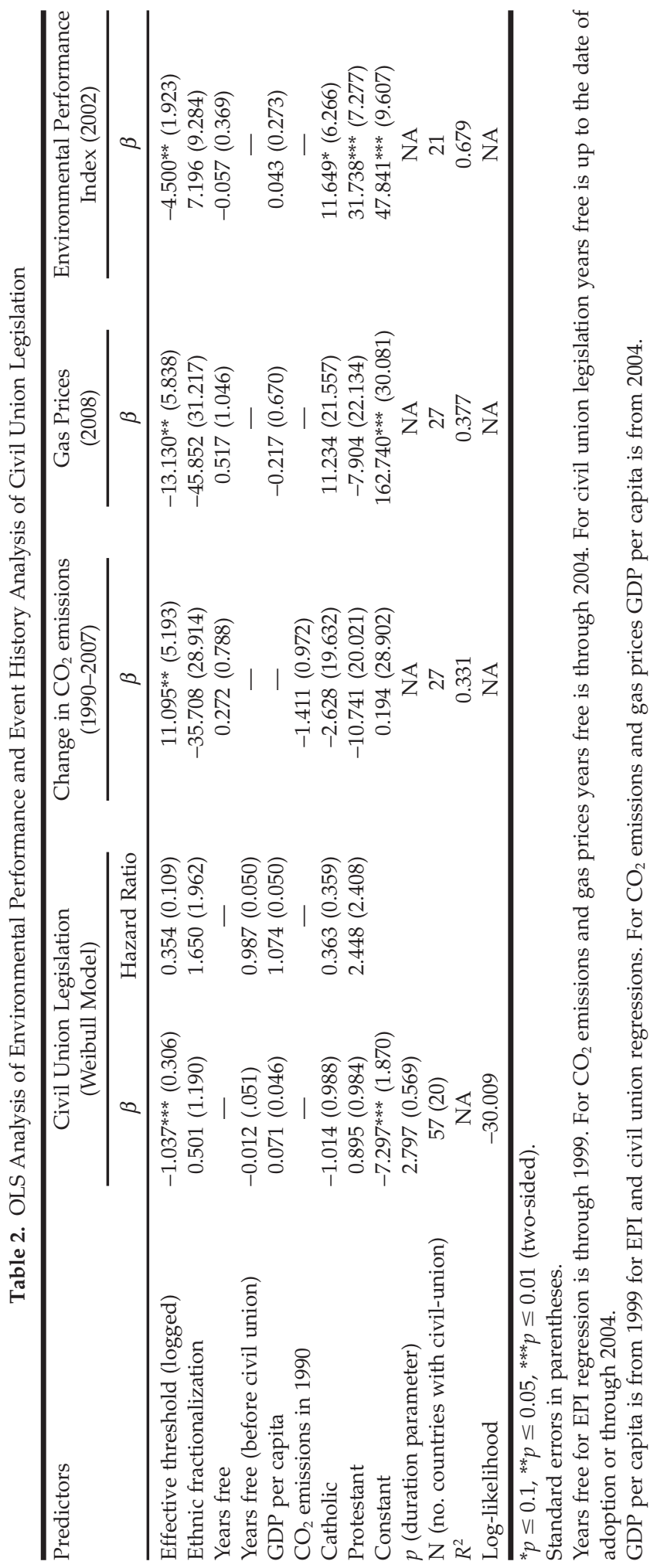




\section{Conclusion}

This paper has argued that electoral institutions influence the political information environment and consequently that they influence policy innovation. Through their influence on the party system, electoral institutions influence how quickly certain policy issues and ideas can be debated, how quickly public opinion will shift on these ideas, and thus how quickly governments can respond to these issues and ideas. In particular, these mechanisms help explain why countries with PR have tended to take earlier action on protecting the environment (i.e., by reducing $\mathrm{CO}_{2}$ emissions) and extending rights to same-sex couples.

It should be noted that while PR produces policy innovation on these issues - that to a great extent lie along the postmaterialism dimension identified by Inglehart (1997) — it may be possible that majoritarian institutional arrangements produce innovation in other policy areas. For example, one of the main advantages claimed by majoritarian systems, such as the UK, is that they concentrate power in the hands of one party and thus produce governments strong and stable enough to impose even unpopular policies (Lijphart, 1999). Conceivably, this advantage could allow majoritarian systems to innovate in certain policy areas. This possibility is best left to future work.

On a related note, historical evidence suggests that majoritarian systems were once innovators on issues such as the extension of voting rights to women. This is an issue that became salient for many democracies at the end of the nineteenth century. In Table 3, it is possible to observe that the countries that became today's multiparty democracies (and that therefore tend to act earlier on modern sensitive issues) have not always been at the forefront of policy innovation. On the contrary, the first two countries to grant women the right to vote (New Zealand and Australia) employed more majoritarian electoral systems, and several other majoritarian countries (Canada, Ireland, the UK, and the United States) were not far behind.

This indicates that at some point, countries with majoritarian systems held the "openness" (information flow) advantage, likely because they tended to have been democratic for a longer period of time, and thus they enjoyed a more open political discourse. Circa 1900, three of the four most democratic countries (with a polity score of 10) were majoritarian countries, while most of the countries that became today's proportional democracies tended to have autocratic characteristics (indicated by the negative polity scores). This suggests that the development of openness can proceed in a dialectical manner. At one point, the development of free and fair elections provided countries with a significant openness advantage. More recently, the openness advantage appears to have shifted to countries that have not only developed free and fair elections but that have also developed institutions that facilitate the expression of diverse perspectives.

There are many important practical implications for these findings beginning with the possibility that these findings could be used to make predictions. We can ask, for example, whether these findings help us predict the direction of policymaking in majoritarian countries like the United States. Can these dynamics also help us predict changes in the developing parts of the world? How will PR affect policy- 
Table 3. Women's Suffrage

\begin{tabular}{|c|c|c|}
\hline Countries & Year Rights Extended & Polity Score Circa 1900 \\
\hline New Zealand & 1893 & 10 \\
\hline Australia $^{a}$ & 1902 & 10 \\
\hline Finland & 1906 & 8 (1917) \\
\hline Norway $^{\mathrm{a}}$ & 1913 & 10 \\
\hline Denmark, Iceland & 1915 & -3 \\
\hline Canada & 1918 & 9 \\
\hline Ireland $^{\mathrm{a}}$ & 1918 & 8 (1921) \\
\hline United Kingdom ${ }^{\mathrm{a}}$ & 1918 & 7 \\
\hline Austria & 1918 & -4 \\
\hline Georgia $^{a}$ & 1918 & NA \\
\hline Germany & 1918 & 1 \\
\hline Estonia & 1918 & 8 (1917) \\
\hline Kyrgyzstan & 1918 & NA \\
\hline Latvia & 1918 & 7 (1920) \\
\hline Poland & 1918 & 8 (1918) \\
\hline Russian Federation & 1918 & -10 \\
\hline Belarus & 1919 & NA \\
\hline Belgium $^{a}$ & 1919 & 6 \\
\hline Luxembourg & 1919 & NA \\
\hline Netherlands & 1919 & -2 \\
\hline Sweden $^{\mathrm{a}}$ & 1919 & -4 \\
\hline Ukraine & 1919 & NA \\
\hline United States & 1920 & 10 \\
\hline Albania & 1920 & -2 \\
\hline Czech Republic & 1920 & 7 (1918) \\
\hline Slovakia & 1920 & 7 (1918) \\
\hline
\end{tabular}

Source: Inter-Parliamentary Union (1997).

Polity scores are for the year 1900 or the earliest year for which data are available for a country. The dates for the latter scores are noted in parentheses.

${ }^{a}$ The right was subject to conditions or restrictions.

making in Latin America? Indeed, several Latin American countries are beginning to extend rights to same-sex couples, while Chile, one of the more majoritarian countries in the region, appears to be moving most slowly on this issue (and other issues related to sexuality, such as abortion and contraception). Perhaps most importantly, these findings may lead us to ask whether the innovation differences discussed here provide countries with tangible advantages. Are the differences in timing relevant to national competitiveness? If so, then significant attention needs to be allocated to ways in which diversity can be increased in the political arena.

Salomon Orellana is a lecturer at the University of Michigan, Dearborn. His research focuses on electoral institutions, information diversity, public opinion, and policymaking.

\section{Notes}

1. The influence of public opinion on policymaking is the subject of several famous studies, including Monroe (1983), Page and Shapiro (1983), Miller and Stokes (1963), Erikson, Wright, and McIver (1993), and Stimson, MacKuen, and Erikson (1995). 
2. See Inglehart and Welzel (2005), Rokeach (1960), Inkeles (1983), Inkeles and Smith (1974), and Lerner (1958).

3. Other issues were considered, but as noted in the next section, there was not as much policy outcome data available for those issues.

4. The proportion of respondents showing support for each issue was calculated by creating a binary variable that divided the responses to the World Values Survey questions into positive and negative responses. On the question pertaining to homosexuality, a value of 1 was assigned to responses of 6 or above. For the question on the environment, a value of 1 was assigned to disagree and strongly disagree. The score for each country, then, is the proportion of citizens that revealed a positive response to homosexuality and protecting the environment.

5. Effective Threshold $=\frac{75 \%}{M+1}$ where $M=$ the average district magnitude. If a national legal threshold represents a higher barrier to party entry, then that value is used instead.

6. According to Cox (1990), district magnitude is the factor that has the largest influence on spatial incentives.

7. For this study, one adjustment is made to this measure. Rather than coding runoff systems as requiring 37.5 percent of the vote (as done by Lijphart), they are coded here as requiring 20 percent of the vote. This is done because runoff systems tend to increase the number of candidates competing for office (see Shugart and Carey, 1992) and should therefore encourage multipartism and a broader political discourse (especially during campaigns) at least more so than pure majoritarian systems that rely solely on majoritarian rules. Runoff systems can also affect public expectations regarding elite behavior. Westholm and Niemi (1992) argue that "systems with proportional representation... or runoff elections... will force voters to think in terms of coalitions and second choices" (p. 31).

8. The source used depends on which allowed the inclusion of the highest number of countries. In one of the models, the CIA World Factbook provided GDP per capita data on a few extra countries.

9. The Pilot Environmental Performance Index is from 2002 and can be found at http://www. ciesin.columbia.edu/indicators/ESI

10. The percentage change in the hazard associated with a unit change in a covariate is: *(Hazard Ratio - 1).

\section{References}

Alesina, Alberto, and Edward L. Glaeser. 2004. Fighting Poverty in the US and Europe: A World of Difference, Rodolfo Debenedetti Lectures. Oxford: Oxford University Press.

Banducci, Susan A., Todd Donovan, and Jeffrey A. Karp. 1999. "Proportional Representation and Attitudes about Politics: Results from New Zealand." Electoral Studies 18 (4): 533-55.

Banducci, Susan A., and Jeffrey A. Karp. 1999. "Perceptions of Fairness and Support for Proportional Representation." Political Behavior 21 (3): 217-38.

Beck, Thorsten, George Clarke, Alberto Groff, Philip Keefer, and Patrick Walsh. 2001. "New Tools in Comparative Political Economy: The Database of Political Institutions." World Bank Economic Review 15 (1): 165-76.

Blais, André, and R. Ken Carty. 1987. “The Impact of Electoral Formulae on the Creation of Majority Governments." Electoral Studies 6 (3): 209-18.

Bowler, Shaun, Todd Donovan, and David Brockington. 2003. Electoral Reform and Minority Representation: Local Experiments with Alternative Elections. Columbus: Ohio State University Press.

Box-Steffensmeier, Janet M., and Bradford S. Jones. 2004. Event History Modeling: A Guide for Social Scientists. Cambridge: Cambridge University Press.

Chang, Eric C. C., and Miriam A. Golden. 2006. "Electoral Systems, District Magnitude and Corruption." British Journal of Political Science 37 (1): 115-37.

Cox, Gary W. 1990. "Centripetal and Centrifugal Incentives in Electoral Systems." American Journal of Political Science 34 (4): 903-35. 
Duverger, Maurice. 1954. Political Parties, Their Organization and Activity in the Modern State. London and New York: Methuen; Wiley.

Ebert, Sebastian, Gerhard P. Metschies, Dominik Schmid, and Armin Wagner. 2009. International Fuel Prices 2009. Eschborn, Germany: Deutsche Gesellschaft für Technische Zusammenarbeit (GTZ).

Erikson, Robert S., Gerald C. Wright, and John P. McIver. 1993. Statehouse Democracy: Public Opinion and Policy in the American States. New York: Cambridge University Press.

European Values Study Group and World Values Survey Association. 2004. "European and World Values Surveys Integrated Data File, 1999-2002, Release I [Computer File]. 2nd ICPSR Version.” Cologne, Germany: Zentralarchiv fur Empirische Sozialforschung (ZA)/Tilburg, Netherlands: Tilburg University/Amsterdam, Netherlands: Netherlands Institute for Scientific Information Services (NIWI)/Madrid, Spain: Analisis Sociologicos Economicos y Politicos (ASEP) and JD Systems (JDS)/ Ann Arbor, MI: Inter-university Consortium for Political and Social Research producers], 2004. Cologne, Germany: Zentralarchiv fur Empirische Sozialforschung (ZA)/Madrid, Spain: Analisis Sociologicos Economicos y Politicos (ASEP) and JD Systems (JDS)/Ann Arbor, MI: Inter-university Consortium for Political and Social Research [distributors].

Gordon, Stacy B., and Gary M. Segura. 1997. "Cross-National Variation in the Political Sophistication of Individuals: Capability or Choice? Journal of Politics 59 (1): 126-47.

Hayward, Janine, and Chris Rudd. 2000. "Metropolitan Newspapers and the Election." In Left Turn: The New Zealand General Election of 1999, ed. Jonathan Boston, Stephen Church, Stephen Levine, Elizabeth McLeay, and Nigel S. Roberts. Wellington: Victoria University Press.

Heidenheimer, Arnold J. 1973. "The Politics of Public Education, Health and Welfare in the USA and Western Europe: How Growth and Reform Potentials Have Differed." British Journal of Political Science 3 (3): 315-40.

Inglehart, Ronald. 1995. "Public Support for Environmental Protection: Objective Problems and Subjective Values in 43 Societies." PS: Political Science and Politics 28 (1): 57-72.

1997. Modernization and Postmodernization: Cultural, Economic, and Political Change in 43 Societies. Princeton, NJ: Princeton University Press.

Inglehart, Ronald, and Christian Welzel. 2005. Modernization, Cultural Change, and Democracy: the Human Development Sequence. New York: Cambridge University Press.

Inkeles, Alex. 1983. Exploring Individual Modernity. New York: Columbia University Press.

Inkeles, Alex, and David Smith. 1974. Becoming Modern: Individual Changes in Six Developing Societies. Cambridge, MA: Harvard University Press.

International Energy Agency. 2009. $\mathrm{CO}_{2}$ Emissions from Fuel Combustion. Paris: International Energy Agency.

Inter-Parliamentary Union. 1997. Men and Women in Politics: Democracy Still in the Making: A World Comparative Study. Geneva: Inter-Parliamentary Union.

Karp, Jeffrey A., Jack Vowles, Susan A. Banducci, and Todd Donovan. 2002. "Strategic Voting, Party Activity, and Candidate Effects: Testing Explanations for Split Voting in New Zealand's New Mixed System." Electoral Studies 21 (1): 1-22.

Katz, Richard S. 1997. Democracy and Elections. New York: Oxford University Press.

Kheng, Yeoh Kok. 2001. "Towards an Index of Ethnic Fractionalization." FEA Working Paper No. 2001-3 [Online]. http://www.fep.um.edu.my/images/fep/doc/2001\%20Pdf/FEA-WP-2001003.pdf. Accessed August 2, 2010.

Kitschelt, Herbert P. 1986. "Political Opportunity Structures and Political Protest: Anti-Nuclear Movements in Four Democracies." British Journal of Political Science 16 (1): 57-85.

Lerner, Daniel. 1958. The Passing of Traditional Society: Modernizing the Middle East. New York: Free Press.

Lijphart, Arend. 1969. "Consociational Democracy." World Politics 21 (2): 207-25.

- 1994. Electoral Systems and Party Systems: A Study of Twenty-Seven Democracies, 1945-1990, Comparative European Politics. Oxford: Oxford University Press.

- 1999. Patterns of Democracy: Government Forms and Performance in Thirty-Six Countries. New Haven, CT: Yale University Press. 
Miller, Warren E., and Donald E. Stokes. 1963. "Constituency Influence in Congress." The American Political Science Review 57 (1): 45-56.

Monroe, Alan D. 1983. "American Party Platforms and Public Opinion." American Journal of Political Science 27 (1): 27-42.

Niemi, Richard G., Guy Whitten, and Mark N. Franklin. 1992. “Constituency Characteristics, Individual Characteristics and Tactical Voting in the 1987 British General Election." British Journal of Political Science 22 (2): 229-40.

Norris, Pippa. 2004. Electoral Engineering: Voting Rules and Political Behavior. Cambridge: Cambridge University Press.

Orellana, Salomon. 2009. "Party Systems and Political Information." Unpublished manuscript.

Page, Benjamin I., and Robert Y. Shapiro. 1983. "Effects of Public Opinion on Policy." The American Political Science Review 77 (1): 175-90.

Persson, Torsten, and Guido Enrico Tabellini. 2003. The Economic Effects of Constitutions, Munich Lectures in Economics. Cambridge, MA: MIT Press.

Powell, G. Bingham. 2000. Elections as Instruments of Democracy: Majoritarian and Proportional Visions. New Haven, CT: Yale University Press.

Rae, Douglas W. 1971. The Political Consequences of Electoral Laws Rev. ed. New Haven, CT: Yale University Press.

Rokeach, Milton. 1960. The Open and Closed Mind. New York: Basic Books.

Shugart, Matthew Soberg, and John M. Carey. 1992. Presidents and Assemblies: Constitutional Design and Electoral Dynamics. Cambridge: Cambridge University Press.

Stimson, James A., Michael B. MacKuen, and Robert S. Erikson. 1995. "Dynamic Representation." The American Political Science Review 89 (3): 543-65.

Westholm, Anders, and Richard G. Niemi. 1992. "Political Institutions and Political Socialization: A Cross-National Study." Comparative Politics 25 (1): 25-41. 